\title{
The Influence of Cinematherapy Against Academic Anxiety in Students
}

\author{
Rubi Rimonda ${ }^{\text {a, }}{ }^{*}$, Siti Zahra Bulantika ${ }^{\text {b, } 2}$, Hammi Latifah ${ }^{c, 3}$, Iswatun Khasanah ${ }^{\text {d, } 4}$ \\ UIN Raden Intan Lampung a,b,c,d \\ ${ }^{1}$ rubi.rimonda11@gmail.com ; ${ }^{2}$ szahrabulantika@gmail.com; ${ }^{3}$ hammilatifah521@gmail.com ; \\ iiskhasanah61@yahoo.com \\ *korespondensi penulis
}

Informasi artikel

Received:

December 14, 2019.

Revised :

January 19, 2019.

Publish :

January 31, 2020.

Kata kunci:

cinematherapy

$\mathrm{cbt}$

kecemasan akademik

Keywords:

academic anxiety

cinematherapy

$c b t$

\begin{abstract}
ABSTRAK
Kecemasan akademik yang tinggi akan menimbulkan penurunan motivasi belajar yang dimiliki oleh peserta didik dalam kegiatan akademik. Keadaan seperti ini akan berdampak buruk pada prestasi belajar yang diraih oleh peserta didik. Tujuan penelitian ini menguji pengaruh cinematherapy terhadap penurunan kecemasan akademik peserta didik. Penelitian ini menggunakan rancangan eksperimen one group pretest-postest design. Subjek penelitian yang digunakan dalam penelitian ini sebanyak 7 peserta didik di SMPN 1 Metro. Pemilihan subjek menggunakan teknik purposive sampling yaitu didasarkan pada kriteria kecemasan akademik tinggi yang diperoleh dari hasil skor skala kecemasan akademik. Teknik analisis data yang digunakan menggunakan uji dependent sample t-test. Berdasarkan hasil uji statistik yang telah dilakukan, menunjukkan bahwa ada pengaruh cinematherapy terhadap penurunan kecemasan akademik peserta didik. Temuan penelitian ini membuktikan cinematherapy efektif terhadap penurunan kecemasan akademik peserta didik di SMPN 1 di kota Metro, Lampung.

ABSTRACT

Students with high academic anxiety can cause a decrease in learning motivation. This situation will damage the learning achievement achieved by students. The purpose of this study was to look at the effect of cinematherapy on reducing student academic anxiety. This study uses a one-group pretest-posttest design experimental design. A total of 7 students in SMP Metro 1 were the subjects in this study. Subject selection uses a purposive sampling technique based on high academic anxiety criteria from the results of the academic anxiety scale score. The data analysis technique used is the Wilcoxon test. Statistical test results show that there is an effect of cinematherapy on the decrease in students' academic anxiety. The findings of this study prove that cinema is effective in reducing student academic anxiety at SMPN 1 in the city of Metro, Lampung.
\end{abstract}

Copyright ${ }^{\circ} 2020\left(\right.$ Rubi Rimonda ${ }^{I}$, Siti Zahra Bulantika ${ }^{2}$, Hammi Latifah $^{3}$, Iswatun Khasanah $\left.{ }^{4}\right)$. All Right Reserved

How to Cite: Rimonda, R., Bulantika, S., Latifah, H., \& Khasanah, I. (2020). The Influence of Cinematherapy Against Academic Anxiety in Students. Jurnal Inspirasi Pendidikan, 10(1), 57-62.

This work is licensed under a Creative Commons Attribution-ShareAlike 4.0 International License. Allows readers to read, download, copy, distribute, print, search, or link to the full texts of its articles and allow readers to use them for any other lawful purpose. The journal hold the copyright. 


\section{Introduction}

The low learning achievement and the difficulty of achieving progress for students is one of the factors that are in the spotlight of the education world. Among the various factors that cause problems and low learning achievement, one of them is anxiety. Generally, when students are confronted with lessons that are considered severe, the teacher's assertiveness in teaching, high grades become orientation. These examinations have been scheduled or not; at the same time, students experience anxiety. Students who find it challenging to learn, in the process of absorbing the subject matter delivered by the teacher will experience difficulties so that he is not optimal and even unable to master the material, tends to avoid the lesson, ignoring the tasks that become his obligation, the decline in grades and learning achievement decline, which will eventually boil down to lazy learning (Rudiansyah, Amirullah, \& Yunus, 2016). Every individual has feelings of anxiety, and most individuals have frightening experiences related to his anxiety problems, and that is a standard part of life. (Yang, Asbury, \& Griffiths, 2019). The way an individual responds to anxiety will have a positive or negative effect on him.

Anxiety can sometimes be useful if it encourages individuals to do the coping they can do. However, if people continue to feel fear, worry prolonged without any effort to reduce or even cure it, then that anxiety will have a bad influence on the person (Rycroft, 2018). The statement is supported by research, which says that the evil power of anxiety makes individuals always think negatively about something that will happen (Bulantika, Wibowo, \& Jafar, 2018), inline with research that says people who experience anxiety, every time will do something or face a problem, always haunted by anxiety, fear, feelings of worry at work (Bulantika, 2019). Feelings of fear of failure and the emergence of the assumption that the inability to complete a task will always haunt people who still feel anxious.

Anxiety levels can reduce motivation and academic achievement. Anxiety is a problem that cannot be ignored by students if they want to achieve academic success in school. If academic anxiety is not handled correctly, it will hurt students such as they will hate the teacher, delaying homework (homework), doing school assignments poorly, playing truant, lying to his parents, and withdrawing from the environment (Thahir, Rimandona, \& Bulantika, 2018). In the educational environment, students have the potential to feel academic anxiety. High academic anxiety can cause a decrease in student motivation to learn. This situation will hurt learning achievement achieved by students (Heller \& Cassady, 2017). Students who are negatively affected by their academic anxiety will cause academic cheating as a form of harm avoidance behavior in learning activities (Chowdhury, 2017). The above problems arise due to the negative thoughts of the students. Negative thoughts will limit the mind, confine, create inner conversations that will weaken the person and will run away from the focus of achieving success in completing academic tasks.

Cinematherapy is a therapy that can be used in dealing with students' academic anxiety problems, namely treatments derived from the Cognitive Behavior Therapy (CBT) approach, the CBT approach has been tested capable of understanding the nature of behavioral disorders, emotional events, and focus on the cognitive content of individual reactions(Alizadeh, Turkestani, Oohadi, \& Rezveh, 2019). CBT is an insight-focused approach that emphasizes recognition and changing negative thoughts and maladaptive beliefs (Spain \& Happé, 2019), testing and restructuring their core beliefs, helping to identify and challenge individual negative thought patterns (Sa'adah \& Rahman, 2015).

CBT aims to reach the core scheme and begin to introduce the idea of restructuring the system by changing the way of thinking, using automatic thoughts, encouraging counselees to consider, and gather evidence to support their beliefs. Individuals tend to maintain their world, feelings, and future (Wilding \& Milne, 2013). Academic anxiety is a problem that originates from negative thoughts that will impact on academic achievement of students. In the treatment of anxiety disorders, CBT can help to identify and challenge individual negative thought patterns. Cinematherapy is a technique or tool to help individuals or groups in coaching, counseling, or therapy so that they are aware and can overcome the problem. (Gregerson, 2010).

Reflection and discussion about language styles, characters, or archetypes in films or videos is the way Cinematherapy does (Shin, 2018). Cinematherapy offers a shared story between the counselor 
and the counselee. The story is presented through the film and chosen to provide a better means of self-understanding, insight, or function for the counselee. Cinematherapy helps individuals to see what happens to themselves or someone through the characters and storylines in the film. (Kangas, Cook, \& Rule, 2017). Recognize aspects of their lives that they cannot dream of, explore the world of themselves by identifying characters, messages, or meanings in films so that a significant decrease in anxiety occurs, adding insight, skills to overcome sadness, emotional catharsis, facilitating cognitive processing and accelerating learning to be able to reduce despair. The film provides a better impact to help overcome individual problems. From the above explanation, academic anxiety can be decreased by cinematherapy techniques.

The use of Cinematherapy techniques has been considered to reduce academic anxiety in individuals. By integrating Cinematherapy into the counseling process, the counselee will get the opportunity to interact dynamically, which emphasizes the emotional response given through film/video and internal dialogue that aims to help individuals recognize and evaluate problems that exist especially the issue of academic anxiety (Rimonda, Wibowo, \& Jafar, 2018). In addition, individuals also learn to engage in more realistic thinking about academic anxiety. After individuals gain insight into how realistic negative thoughts are about the effects of academic anxiety, individuals will be taught to act, feel, and fight negative thoughts.

\section{Method}

This experimental research is one group pretest-posttest design. The study was conducted two measurements. Measurement of pretest-posttest, giving instruments/data collection (academic anxiety scale) to find out the initial description of the level of academic anxiety of students before being given treatment, and the final picture of the level of academic anxiety of students after treatment. Therapy is a cinematherapy that is conducted in 4 meetings, with the frequency of each meeting between one to two times a week, and 90 minutes. Subject selection with purposive sampling technique. The subjects of the study were students of SMPN 1 Metro who were identified as having academic anxiety problems, as many as seven people, with one experimental group. Data collection techniques using an anxiety scale, the adaptation of The Achievement Emotions Questionnaire (AEQ, Pekrun, Goetz, Titz, \& Perry, 2006). The number of items in AEQ is 24 items. The indicators include three subscales, namely eight items related to learning anxiety, eight items related to class anxiety, and eight items of anxiety test. This instrument has been tested for instrument reliability, with a score of 0.855 . Data analysis techniques to test hypotheses using the Wilcoxon test.

\section{Result and Dicussion}

Hypothesis testing to test $\mathrm{H} 1$ uses Wilcoxon analysis techniques. Wilcoxon test to determine differences in the results of pretest and posttest experiments. Data collected (pretest, posttest) are tabulated and then analyzed. The condition of the academic anxiety of students before getting treatment on average is at a high level. After getting treatment, the level of academic anxiety of students showed a decrease in scores and became a medium category, and low. The results can be seen in table 1

Table 1. Wilcoxon Test Results

\begin{tabular}{lllcc}
\hline Parameter & Pretest & Posttest & Z & $\begin{array}{c}\text { Asymp. Sig } \\
(2 \text {-tailed })\end{array}$ \\
\hline Mean & 97.16 & 32.14 & $-2.460^{\mathrm{a}}$ & .014 \\
Std. Deviation & 4.31 & 4.95 & & \\
\hline
\end{tabular}

Based on the results of the one-group pretest-posttest design test, the average pretest results of the students' academic anxiety level were at high criteria (pretest, $\mathrm{M}=97.16, \mathrm{SD}=4.31$ ). After being given a cinematherapy treatment posttest results, the average level of academic anxiety of students becomes a low criterion (posttest, $\mathrm{M}=32.14, \mathrm{SD}=4.95$ ). So from the results of the analysis shows that cinematherapy gives an influence in reducing the academic anxiety of students in SMPN 1 Metro. 
The statistical test results in the calculated $\mathrm{Z}$ value is -2.628 . This, after being consulted in table $\mathrm{Z}$, the significance level is $5 \%$ or 0.05 , the value is around -1.645 , while the Asymp amount. Sig (2-tailed) obtained 0.014 because $\mathrm{Z}$ count is more than $\mathrm{Z}$ table that is $-2.628>-1.645$ or sig value $0.014<0.05$ then the Ho hypothesis which reads "there is a cinematherapy effect on reducing the level of academic anxiety of students of SMPN 1 Metro 2019/2020 Academic Year" was accepted because it was tested for its truth.

Based on the statistical tests listed in tables 1 and 2, there are significant differences between before and after the intervention. It can be concluded that cinematherapy is effective in reducing the level of academic anxiety of students. This means that cinematherapy has an effect on reducing the academic anxiety of students of SMPN 1 Metro, and can be one of the solutions for counseling guidance teachers to help overcome students' academic anxiety problems.

Academic anxiety is the result of biochemical processes in the body and brain of individuals who need and increase attention (Alam, 2018). With regard to academic situations, changes occur in responses such as discussions in class or during exams, and completing assignments at school (Roos et al., 2017). When anxiety increases, the body's reaction will respond to reject or fight it. Academic anxiety causes worries that can make it difficult for students to concentrate on a variety of tasks including reading, writing, listening and speaking (Ely \& Jastrowski-Mano, 2019), learners who suffer from academic anxiety may have distracting thoughts and prevent them from thinking logically and clearly.

Research that has been done explains that anxiety can affect the learning process of students (Pizzie \& Kraemer, 2019). This study concludes that students 'academic anxiety is closely related to their learning process because when students' academic anxiety increases, the learning process becomes ineffective. Students who experience anxiety, lose the process of regulation in themselves that involves short and medium-term memory so that it will show the response to the difficulty instructing information (AlKandari, 2017). This fact is in line with Lab research that shows that anxiety reduces the activity in organizing information in memory (Kumari, 2018).

Cinematherapy is part of the CBT theory that can be used in therapy. Therefore, cinematherapy can play an essential role in understanding individual maladaptive thoughts and beliefs and can also reconstruct cognition (Carpenter, Redcay, \& Freeman, 2017). Through cinematherapy, individuals can understand what must be done because of the influence of the film that can motivate. Based on the view of social learning theory, cinematherapy can be a catalyst for the development and alleviation of problems for individuals who are always learning and influencing them with full awareness. Cinematherapy is a useful technique for improving mental health for adolescents, effective in affective, cognitive, and behavioral modeling processes (Setiawati, Islamarinda, Nuryono, \& Naqiyah, 2018), appropriate to improve self-concept, increase self-confidence, provide careful reviewing of learning to individuals by providing opportunities to choose between different behaviors and attitudes based on the means available. Thus, it can be applied in their own lives, because the meaning of film has the potential to be a seed to reframe problems, develop personally, and model healthy problem solving (Kim \& Kim, 2016). If the cinematherapy technique is applied correctly, it will build the desire or awareness of students to achieve an expected goal that is to reduce academic anxiety disorders that have an impact on their lives.

With the high anxiety experienced by students, it will significantly affect the learning outcomes, so it is very much needed assistance from the supervising teachers, especially counselors in dealing with students who experience high academic anxiety. Based on the findings, opinions, and results of relevant research, it can be concluded that the cinematherapy technique can be used by counselors to help students overcome the problem of academic anxiety.

\section{Conclusion}

This research was conducted to see the effect of cinematherapy on the reduction of social anxiety in SMPN 1 Metro students. The results showed that through cinematherapy and significantly reduced the academic anxiety of students at SMPN 1 Metro.

Hopefully, the results of this study will be useful for guidance, and counseling teachers in schools can use cinematherapy techniques to overcome the problems of other students in general. 
Cinematherapy can also be done in a different culture and level of education besides junior high school, such as vocational or high school.

\section{References}

Alam, M. M. (2018). Study of academic anxiety and academic achievement across certain demographic factors. Scholarly Research Journal for Interdisciplinary Studies, 6, 46.

Alizadeh, M., Turkestani, N. A., Oohadi, B., \& Rezveh, F. M. (2019). Effectiveness of cognitive behavioral counseling-based film therapy on the communication skills of females with low sexual Desire. Journal of Nursing and Midwifery Sciences, 6(1), 8.

AlKandari, N. Y. (2017). Female college students' academic anxiety at Kuwait University. Psychology and Education: An Interdisciplinary Journal.

Bulantika, S. Z. (2019). Efektivitas Konseling Individual Menggunakan Teknik Brainstorming untuk Meningkatkan Komunikasi Interpersonal. Ghaidan: Jurnal Bimbingan Konseling Islam Dan Kemasyarakatan, 3(2), 24-30.

Bulantika, S. Z., Wibowo, M. E., \& Jafar, M. (2018). Group Counseling with Systematic Desensitization Techniques and Thought-Stopping Techniques to Reduce Social Anxiety. Jurnal Bimbingan Konseling, 7(2), 106-112.

Carpenter, B. C., Redcay, A., \& Freeman, A. (2017). Tools for enhancing resilience and addressing internalized heterosexism: Bibliotherapy and cinematherapy in groupwork for individuals who come out as an adult. Groupwork, 27(3).

Chowdhury, R. (2017). Rana Plaza fieldwork and academic anxiety: Some reflections. Journal of Management Studies, 54(7), 1111-1117.

Ely, S., \& Jastrowski-Mano, K. (2019). An Exploratory Look at the Effects Gender \& Other Demographic Variables on Test Anxiety in College Students. Undergraduate Scholarly Showcase Program (Spring 2019).

Gregerson, M. B. (2010). The cinematic mirror for psychology and life coaching. Springer.

Heller, M. L., \& Cassady, J. C. (2017). The impact of perceived barriers, academic anxiety, and resource management strategies on achievement in first-year community college students. Journal of The First-Year Experience \& Students in Transition, 29(1), 9-32.

Kangas, T. C., Cook, M., \& Rule, A. C. (2017). Cinematherapy in gifted education identity development: Integrating the arts through STEM-themed movies. Journal of STEM Arts, Crafts, and Constructions, 2(2), 3.

Kim, H. G., \& Kim, J. S. (2016). The Effects of Group Cinema Therapy Program on Self-Esteem and Interpersonal Relationship in Nursing Students. Journal of Korean Public Health Nursing, 30(3), 583-594.

Kumari, M. (2018). A Study of Academic Anxiety in Relation to Mental Health in Adolescents. Int J Cur Res Rev| Vol, 10(6), 26.

Pizzie, R. G., \& Kraemer, D. J. M. (2019). The Academic Anxiety Inventory: Evidence for dissociable patterns of anxiety related to math and other sources of academic stress. Frontiers in Psychology, 9, 2684.

Rimonda, R., Wibowo, M. E., \& Jafar, M. (2018). The Effectiveness of Group Counseling by Using Cognitive Behavioral Therapy Approach with Cinematherapy and Self-talk Techniques to Reduce Social Anxiety at SMK N 2 Semarang. Jurnal Bimbingan Konseling, 7(2), 145-152.

Roos, A.-L., Bieg, M., Goetz, T., Frenzel, A., Taxer, J., \& Zeidner, M. (2017). Experiencing more anxiety than expected?: trait and state mathematics anxiety in high achieving students. ESCoP 2017: 20th Conference of the European Society for Cognitive Psychology, 36-37. 
Rudiansyah, R., Amirullah, A., \& Yunus, M. (2016). Upaya Guru dalam Mengatasi Kecemasan Siswa dalam Menghadapi Tes (Pencapaian Hasil Belajar) Siswa di SMP Negeri 3 Banda Aceh. Jurnal Ilmiah Mahasiswa Pendidikan Kewarganegaraan, 1(1).

Rycroft, C. (2018). Anxiety and neurosis. Routledge.

Sa'adah, F. M., \& Rahman, I. K. (2015). Konsep bimbingan dan konseling cognitive behavior therapy (CBT) dengan pendekatan Islam untuk meningkatkan sikap altruisme siswa. Hisbah: Jurnal Bimbingan Konseling Dan Dakwah Islam, 12(2), 49-59.

Setiawati, D., Islamarinda, K. M., Nuryono, W., \& Naqiyah, N. (2018). Counselors' Role to Improve The Resilience Broken Home Students of Junior High School. 2nd International Conference on Education Innovation (ICEI 2018). Atlantis Press.

Shin, K. A. (2018). Effect of the Cinema Therapy Program for Middle-Aged Women with Depression. Journal of Digital Convergence, 16(10), 511-522.

Spain, D., \& Happé, F. (2019). How to Optimise Cognitive Behaviour Therapy (CBT) for People with Autism Spectrum Disorders (ASD): A Delphi Study. Journal of Rational-Emotive \& CognitiveBehavior Therapy, 1-25.

Thahir, A., Rimandona, R., \& Bulantika, S. Z. (2018). Cinematherapy and Thought-Stopping Techniques to Reduce Social Anxiety. Proceedings International Conference of Counseling Education and Psychology (ICONCEP), 1 .

Wilding, C., \& Milne, A. (2013). Cognitive Behavioural Therapy, Terjemahan. Ahmad Fuandy. Jakarta: PT. Indeks.

Yang, Z., Asbury, K., \& Griffiths, M. D. (2019). An exploration of problematic smartphone use among Chinese university students: Associations with academic anxiety, academic procrastination, self-regulation and subjective wellbeing. International Journal of Mental Health and Addiction, 17(3), 596-614. 